\title{
IкB $\xi$, an atypical member of the inhibitor of nuclear factor kappa $B$ family, is induced by $\gamma$-irradiation in glioma cells, regulating cytokine secretion and associated with poor prognosis
}

\author{
HEIKO BRENNENSTUHL ${ }^{1}$, ANGELA ARMENTO ${ }^{1}$, ANNE KRISTIN BRACZYSNKI ${ }^{2}$, \\ MICHEL MITTELBRONN ${ }^{2}$ and ULRIKE NAUMANN ${ }^{1}$ \\ ${ }^{1}$ Hertie Institute for Clinical Brain Research and Center Neurology, Molecular Neurology, \\ Karl Eberhards University of Tübingen, Tübingen; ${ }^{2}$ Edinger Institute \\ (Neurological Institute), Goethe University, Frankfurt am Main, Germany
}

Received June 22, 2015; Accepted August 3, 2015

DOI: 10.3892/ijo.2015.3159

\begin{abstract}
The inhibitor of nuclear factor kappa B zeta (IкB $\zeta$ ) is an atypical member of the I $\kappa$ B protein family. Its function in regulating the activity of the transcription factor nuclear factor kappa B (NFKB) as well as its involvement in cancer-associated processes is poorly understood. In glioma patients, enhanced expression of I $\mathrm{I} B \zeta$ in tumor specimen is associated with poor prognosis. Here we report that $I \kappa B \zeta$ is upregulated in a glioma cell line resistant towards $\mathrm{NF \kappa B}$-dependent non-apoptotic cell death. Upon $\gamma$-irradiation of glioma cells, IкB $\zeta$ expression is enhanced, and subsequently serves as a transcriptional activator of the tumor promoting cytokines interleukin (IL-6), IL-8 and chemokine (C-X-C motif) ligand 1 (CXCL1) that are known to be involved in glioma associated inflammatory processes. In contrast, shRNA-mediated knockdown of IкB $\zeta$ reduces the expression of the aforementioned cytokines. We propose a previously unappreciated role of $I \kappa B \zeta$ in the inflammatory micromilieu as well as progression in glioma.
\end{abstract}

Correspondence to: Professor Ulrike Naumann, Hertie Institute for Clinical Brain Research and Center Neurology, Department of Vascular Neurology, Molecular Neurology, Karl Eberhards University of Tübingen, Otfried-Müller-Str. 27, D-72076 Tübingen, Germany

E-mail: ulrike.naumann@uni-tuebingen.de

Abbreviations: CCL2, chemokine (C-C motif) ligand 2; CNS, central nervous system; CTS-1, chimeric tumor suppressor 1; CXCL1, chemokine (C-X-C motif) ligand 1; DMEM, Dulbecco's modified Eagle's medium; DOX, doxycycline; FCS, fetal calf serum; GBM, glioblastoma; IкB $\zeta$, inhibitor of nuclear factor kappa B zeta; IL, interleukin; MCP-1, monocyte chemoattractant protein; NFkB, nuclear factor kappa B; rtTA, reverse tetracycline repressor; STAT, signal transducer and activator of transcription; TNFa, tumor necrosis factor alpha; VEGF, vascular endothelial factor

Key words: glioma, IкB $\zeta$, inflammatory cytokine expression, radiation

\section{Introduction}

The vast majority of cellular activities are executed by coordinated gene expression. Precise regulation of the transcription factors that control gene expression is necessary to accomplish specific tasks and to maintain cellular homeostasis. Various endogenous and exogenous stimuli induce changes in gene expression, and dynamic changes of gene expression profiles are observed during all processes maintaining life. Deregulated gene expression by either genetic or epigenetic alterations on the other hand can cause a broad range of diseases and is important for the development of cancer. The transcription factor $\mathrm{NF} \kappa \mathrm{B}$ plays a central role in many biological processes such as inflammation, differentiation, cell death and tumorigenesis (1). In glioblastoma (GBM), the most malignant human brain tumor in man, overexpression or aberrant constitutive activation of NFKB contributes to survival (2), radio- and chemoresistance (3-5), elevated glioma cell motility $(6,7)$, enhanced angiogenesis (8) as well as chronic inflammation (9). On the other hand it has been described that, under some circumstances and dependent on the cooperation of NFKB with a variety of other, yet mainly unidentified factors and modulators of its activity, $\mathrm{NF \kappa B}$ is mandatory for the induction of cell death, even in GBM cells (10-12). Until today it has not been unraveled in detail by which mechanisms NFKB provides its dual function, either serving as an oncogene triggering survival, but also exerting, via induction of cell death, its function as a tumor suppressor. Plenty of suggestions exist as to how and by which factors the dual function of $N F \kappa B$ is regulated, but there are still many questions left.

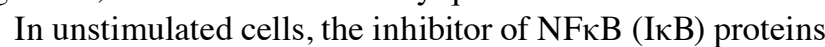
sequester NFKB into inactive complexes in the cytoplasm. A variety of different stimuli such as hypoxia, stress or tumor necrosis factor $\alpha(\mathrm{TNF} \alpha)$ can induce, via different pathways, the phosphorylation of cytoplasmic IкB protein family

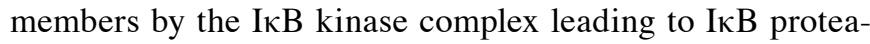
somal degradation, this resulting in the nuclear translocation of NFkB and induction of target gene expression (13). Whereas the predominantly cytoplasmic family members I $\mathrm{K} B \alpha$, IкB $\beta$ and $\mathrm{I} \kappa \mathrm{B} \varepsilon$ exclusively act as inhibitors of $\mathrm{NF} \kappa \mathrm{B}$, the atypical 
and mainly nuclearly localized $\mathrm{I} \kappa \mathrm{B}$ protein $\mathrm{I} \kappa \mathrm{B} \zeta$, coded by the NFKBIZ gene and being a primary response target gene of $\mathrm{NF} \kappa \mathrm{B}$ (14), is able to bind to $\mathrm{NF} \kappa \mathrm{B}$, is postulated to work as a (co)-transcription factor, and in this way seems to modulate the expression of a subset of NFkB target genes. Modulation of gene expression is at least partially mediated by the intrinsic transactivation activity of $\mathrm{I} \kappa \mathrm{B} \zeta$ and its interaction with the $\mathrm{NF} \kappa \mathrm{B}$ subunit p50 $(15,16)$. Moreover, $\mathrm{I} \kappa \mathrm{B} \zeta$ is associated with histone deacetylases suggesting that chromatin remodeling is important for the transcriptional activity of $\mathrm{I} \kappa \mathrm{B} \zeta(17)$. In this report we demonstrate that $\mathrm{I} \kappa \mathrm{B} \zeta$ is upregulated in glioma specimens, in primary low passage glioma cells as well as in most established glioma cell lines. In a glioma cell line resistant towards NFאB-dependent cell death that is induced by overexpression of a dominant active p53 variant the chimeric tumor suppressor-1 (CTS-1) $(12,18), \mathrm{I} \kappa \mathrm{B} \zeta$ is highly upregulated. In this regard we were interested whether I $\kappa \mathrm{B} \zeta$ might be a candidate that regulates the switch between the dual functions of $\mathrm{NF \kappa B}$ : serving as an oncogene or acting as a cell death inductor and tumor suppressor.

Recently it has been described that $\mathrm{I} \kappa \mathrm{B} \zeta$ is an important regulator of radiation induced cellular senescence in breast cancer cells (19). Subsequently, senescence associated proteins such as interleukins, chemokines or growth factors can signal to the tumor environment and could potentially promote tumor progression by promoting proliferation, invasion or angiogenesis (20) or by induction of detrimental chronic inflammatory immune responses (21). Additionally, $\mathrm{I} \kappa \mathrm{B} \zeta$ has been described as a regulator of chemokine (C-C motif) ligand 2 , recruiting circulating monocytes to inflammatory regions (14). Radiation is a common approach in the treatment of glioma. In this regard it is postulated that irradiation, via induction of necrosis, might lead to (chronic) inflammatory processes in the tumor micro-milieu and subsequent induction of resistance towards radiation (reviewed in ref. 22). We were also interested whether in glioma $\mathrm{I} \kappa \mathrm{B} \zeta$ expression is regulated by $\gamma$-irradiation and if in this context $\mathrm{I} \kappa \mathrm{B} \zeta$ serves as a transcriptional inducer of inflammatory chemokine and cytokine secretion, this way putatively inducing a more malignant tumor phenotype by modulating the tumor micro-milieu. Our data provide novel information on the role of $\mathrm{I} \kappa \mathrm{B} \zeta$ in tumorigenesis and tumor progression in glioma.

\section{Materials and methods}

Cell lines, reagents. The LN-229 (here named LNT-229P) cell line is a human malignant glioma cell line and was kindly provided by N. de Tribolet (Lausanne, Switzerland). Generation of CTS-1 resistant cell line LNT-229R was previously described (12). GBM primary cells were established from human GBM tissue and used at passages 5-8. All cells were maintained in Dulbecco's modified Eagle's medium (DMEM; Gibco Life Technologies, Eggenstein, Germany) containing $10 \%$ tetracycline-approved fetal calf serum (Tet-FCS; Gibco), penicillin $(100 \mathrm{U} / \mathrm{ml})$ and streptomycin $(100 \mu \mathrm{g} / \mathrm{ml})$ in a humidified atmosphere containing $5 \% \mathrm{CO}_{2}$. Cell culture growth and cellular density was determined by crystal violet staining as described. For irradiation, the cells were seeded in 6-well plates and irradiated using the Nordion GC40 Gammacell irradiator (Ottawa, ON, Canada). For generation of supernatants, the cells were treated as indicated, serum-free medium was added and cellular supernatants were harvested 24 or $48 \mathrm{~h}$ later. The protein content in supernatants was analyzed according to Bradford.

Transfection of cells with shRNA constructs. For transfection with shRNA contructs, the cells were seeded at $3 \times 10^{5}$ cells. After attachment, the cells were transfected with plasmid constructs coding for either $\mathrm{I} \kappa \mathrm{B} \zeta$ specific shRNA, or coding for scrambled shRNA unspecific for any known mRNA using Metafectene PRO (Biontex, Martinsried, Germany). shRNA plasmid constructs were a kind gift of Klaus SchulzeOsthoff (Interfaculty Institute for Biochemistry, University of Tübingen, Germany).

$R N A$ preparation and quantitative $R T-P C R$. Total RNA was prepared using the High Pure RNA Isolation kit (Roche, Mannheim, Germany). RNA (5 $\mu \mathrm{g})$ was reverse transcribed using Superscript II reverse transcriptase (Invitrogen, Carlsbad, CA, USA). Target gene expression was determined using SYBR green master mix (Thermo Fisher Scientific, MA, USA), on an ABI 7200 system. Relative mRNA expression was quantified using comparative $2^{-\Delta \Delta \mathrm{C}_{\mathrm{T}}}$ method $\left\{\left[\mathrm{E}^{\Delta \mathrm{CT}}\right.\right.$ (TARGET)/ $\left.\mathrm{E}^{\Delta \mathrm{CT}}(\mathrm{GAPDH})\right]$ \}. The following primers were used: I $\kappa$ B $\zeta$-frwd (TCTGGAACTCATTCGCCTCT), I $\kappa$ B $\zeta$-rev (TCAACCGATACTGCAAGCTG), IL-6-frwd (CGGGAACG AAAGAGAAGCTCTA), IL-6-rev (GGCGCTTGTGGAGA AGGAG),IL-8-frwd(GTGGAGAAGTTTTTGAAGAGGGC), IL-8-rev (CACTTCATGTATTGTGTGGGTCTG), CXCL-1frwd (GCAGGGAATTCACCCCAAGA), CXCL-1-rev (GAT GCAGGATTGAGGCAAGC), GAPDH-frwd (TGCACCAC CAACTGCTTAGC), GAPDH-rev (GGCATGGACTGTGG TCATGA). GAPDH was used for internal normalization and did not vary between cell types or treatments.

Construction of adenoviral vectors and adenoviral infection. A replication-deficient recombinant and tetracycline-inducible adenovirus expressing $\mathrm{I} \kappa \mathrm{B} \zeta$ was constructed using the Ad-Easy system (23). In brief, I $\kappa \mathrm{B} \zeta$ cDNA was inserted into pTRE-tight (Takara Bio Europe SAS, Saint-Germain-en-Laye, France) downstream of the tetracycline-responsive promoter element. The inserted cDNA was completely sequenced, compared to the NCBI database and found to be correct. The expression cassette consisting of the CMV-minimal promoter, the Tet-responsive element and $\mathrm{I} \kappa \mathrm{B} \zeta \mathrm{cDNA}$ was cloned into pAdTrack, containing an additional expression cassette for enhanced green fluorescence protein (EGFP), which was later used to monitor virus production and infection load. After recombination with the viral genome containing plasmid Ad-Easy1, recombinant adenoviral genomes were transfected into HEK-293 cells (ATCC). Ad-ON expresses the reverse TET-repressor (rtTA) and was a kindly gift of G. Thomas (Portland, OR, USA), Ad-CTS1, coding for a dominant active version of p53, has been previously described (18), Ad-Co\#4, which serves a control virus, is based on the Ad-Easy-System, but lacks both EGFP and expression of the gene of interest. All viruses were $\mathrm{CsCl}$-purified, dialyzed and titrated using the Clontech Adeno-X Rapid Titration System. Transgene expression and inducibility were tested by quantitative RT-PCR (qPCR) of infected LNT-229P cells. Infection with recombinant 
adenovirus was accomplished by exposing cells to adenovirus at a defined moiety of infection (MOI) in serum-free medium for $30 \mathrm{~min}$ followed by addition of serum-containing medium of the mentioned time periods.

$N F \kappa B$ luciferase reporter assay. LNT-229P cells grown in microtiter plates were transfected with $150 \mathrm{ng}$ pNF $\kappa$ B-Luc expressing firefly luciferase and $20 \mathrm{ng}$ pRL-CMV expressing renilla luciferase as an internal standard. As a positive control of NFKB activation, the cells were cotransfected with $40 \mathrm{ng}$ pMEKK. At $24 \mathrm{~h}$ after transfection, the cells were infected with $100 \mathrm{MOI}$ of Ad TET-IкB $\zeta+100 \mathrm{MOI}$ of Ad-ON in the absence or presence of doxycycline $(2 \mu \mathrm{g} / \mathrm{ml})$ for $48 \mathrm{~h}$. NFKB activity was assessed using the dual luciferase assay (24).

Detection of cytokine expression. Relative cytokine expression was analyzed using the RayBiotech Human Cytokine Array (RayBiotech, Norcross, GA, USA) according to the manufacturer's protocol. Cell culture supernatants were harvested at indicated time points and stored at $-20^{\circ} \mathrm{C}$. In parallel, RNA was harvested from the cells for cDNA synthesis and subsequent qPCR analysis of cytokine mRNA expression. Intensity of the spots on the array was normalized to the mean intensity of the internal control spots and relative intensity was measured from duplicate dots representing single cytokines. For the analysis of absolute amounts of IL-6, the cells were treated as indicated and IL-6 secretion was measured using an IL-6 immunoassay kit (RayBiotech).

TCGA and REMBRANDT analyses. $\mathrm{I} \kappa \mathrm{B} \zeta$ gene expression was analyzed in primary glioma and normal brain samples by assessing the TCGA data portal. The mRNA profiles were determined using the Agilent 244K G4502A microarray (http://cancergenome.nih.gov/; accessed Dec. 2014). Statistical significance between GBM and normal CNS tissue was assessed using a t-test $(\mathrm{p}<0.05)$. The calculations were performed using GraphPad Prism Software 6.0 (GraphPad Software, CA, USA). Survival correlation analyses were done using the REMBRANDT database containing probes from the Affymetrix 223218_s_at and 223217_s_at dataset (National Cancer Institute; 2005; REMBRANDT version 1.5.9, http:// rembrandt.nci.nih.gov). At the time of accession (Dec. 2014), the database contained mRNA data of 228 glioblastomas, 148 grade II/III astrocytomas, 67 grade II/III oligodendrogliomas, 11 mixed gliomas and 28 non-tumor control tissues. Kaplan-Meier survival curves were generated by analyzing the glioma cohort (WHO grade II-IV; $n=138$ ) as well as the GBM cohort (WHO grade IV; $n=84$ ) separately. I $\kappa$ B $\zeta$ up- or downregulation was defined as a twofold (or greater) difference from the mean expression level within a given dataset. p-values for differences in patient survival curves were obtained by using the log-rank or Wilcoxon test. The 'Highest Geometric Mean Intensity' of $\mathrm{I} \kappa \mathrm{B} \zeta$ expression was used as the reporter for relative $\mathrm{I} \kappa \mathrm{B} \zeta$ expression within the database.

Statistical and correlation analysis. The figures show data obtained in at least three independent experiments as indicated. Statistical analyses were performed using GraphPad Prism version 6.0 (GraphPad Software, CA, USA). Quantitative data were assessed for significance by paired t-test $\left({ }^{*} \mathrm{p}<0.05\right.$;
A

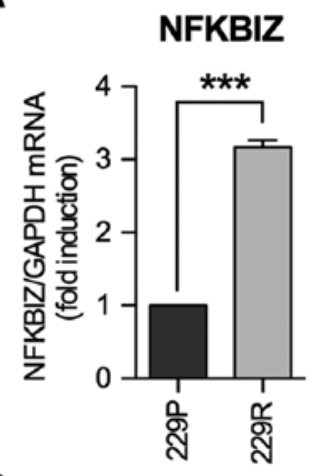

B

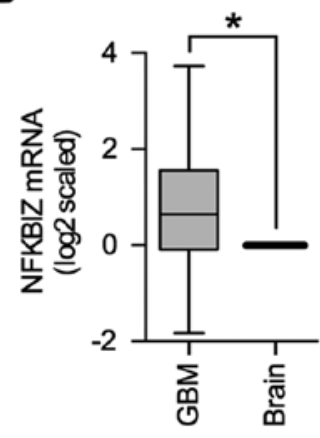

C

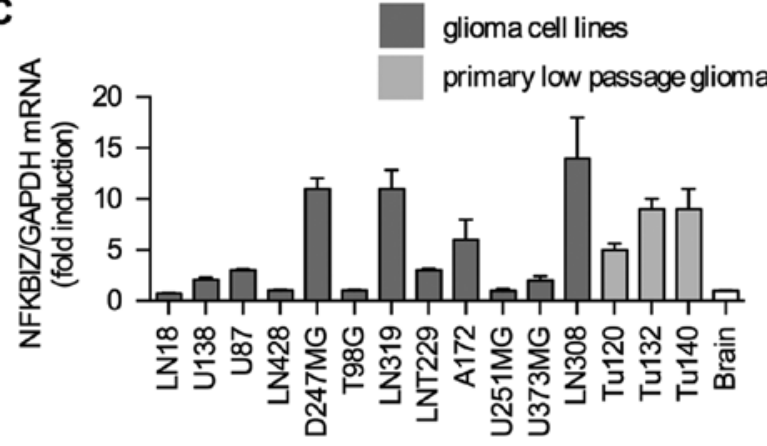

D

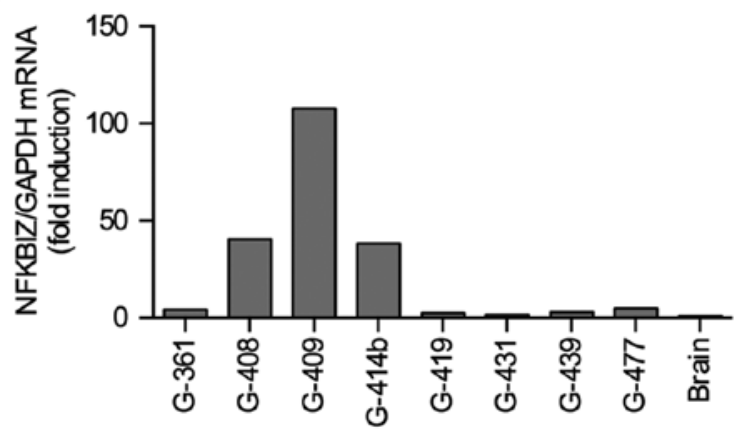

Figure 1. I $\mathrm{B} \zeta \zeta$ mRNA expression is upregulated in most glioma cells (A) Basal I $\mathrm{I} B \zeta$ mRNA expression in LNT-229P and CTS-1 resistant sibling LNT-229R cells $\left(\mathrm{n}=3\right.$, SEM, $\left.{ }^{* * *} \mathrm{p}<0.001\right)$. (B) Analysis of the TCGA glioma dataset (AgilentG4502A_07). $\log _{2}$ scaled tumor/normal ratio of NFKBIZ. IкB $\zeta$ mRNA expression was found to be $0.65\left(\log _{2}\right)$-fold increased in glioblastoma compared to non-tumor brain tissue (Wilcoxon test, ${ }^{*} \mathrm{p}<0.05$ ). $(\mathrm{C}$ and $\mathrm{D})$ Comparison of $\mathrm{I} \kappa \mathrm{B} \zeta \mathrm{mRNA}$ expression in established and primary glioma cell lines (C) and glioma specimen (D) showed increased ІкB $\zeta$ mRNA in 8/12 established cell lines, $3 / 3$ primary glioma cell lines and in $7 / 8$ glioma specimens.

$\left.{ }^{* *} \mathrm{p}<0.01 ;{ }^{* * *} \mathrm{p}<0.001\right)$. Patient survival was analyzed by KaplanMeier life table and for comparison of survival Wilcoxon and log-rank test were used (significance level $\alpha=0.05$, JMP 11.0 software, SAS, Cary, NC, USA).

\section{Results}

I $\kappa$ B $\zeta$ mRNA is upregulated in low passage glioma cell lines, established cell lines and glioma specimens. We generated a cell line (LNT-229R) completely resistant to NFKB-dependent cell death induction upon overexpression of a dominantpositive p53, chimeric tumor suppressor (CTS)-1 (12). In a microarray mRNA expression analysis, I $\mathrm{I} \mathrm{B} \zeta$ was upregulated in LNT-229R cells (12) suggesting that in GBM IкB $\zeta$ might 
A

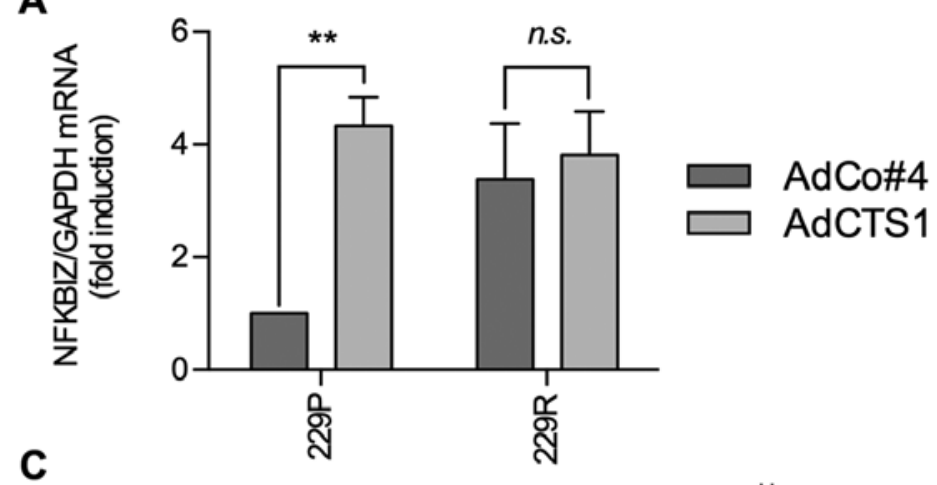

C

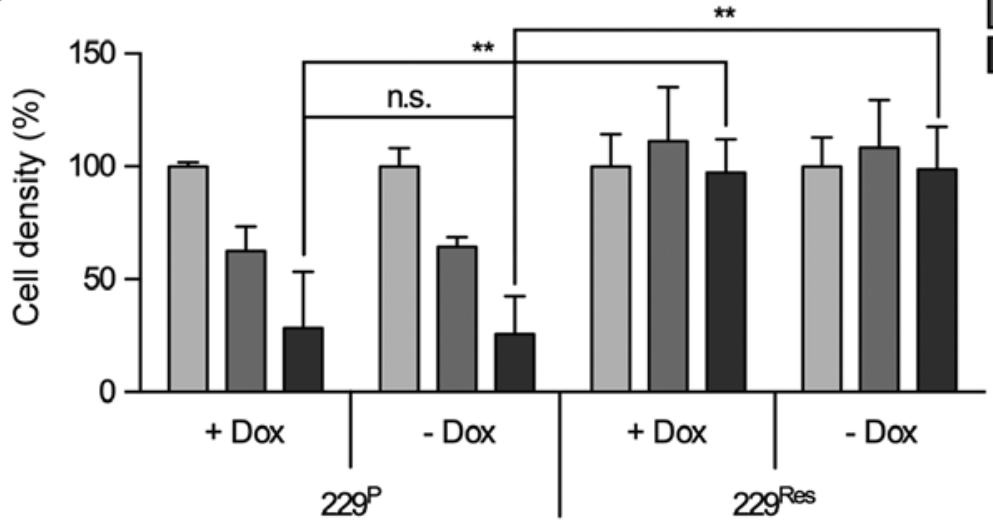

B

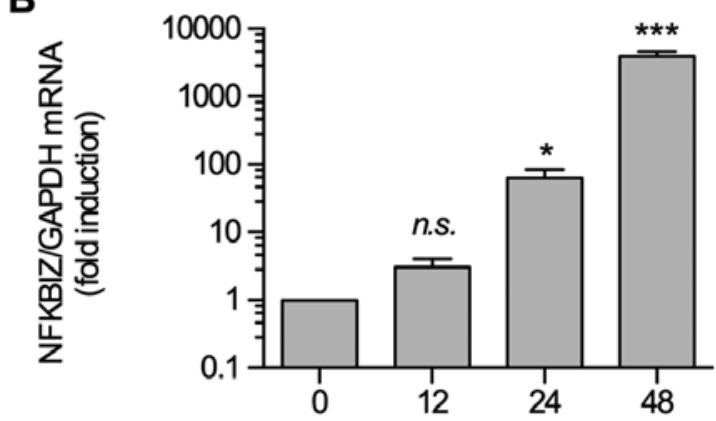

D

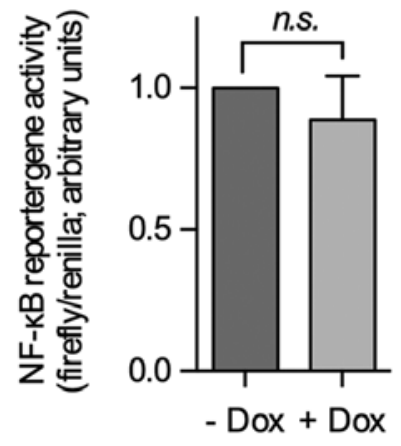

Figure 2. I $\kappa \mathrm{B} \zeta$ overexpression neither modulates $\mathrm{NF} \kappa \mathrm{B}$ activity nor protects glioma cells from $\mathrm{CTS}-1$ induced cell death. (A) I $\kappa \mathrm{B} \zeta \mathrm{mRNA}$ expression in LNT229P and LNT229R cells after infection with Ad-CTS-1. AdCo\#4 served as a negative control (n=4, SEM, ${ }^{* *}$ p $\left.<0.01\right)$. (B) Upon adenoviral infection and induction of transgene expression by addition of DOX, I $\kappa \mathrm{B} \zeta \mathrm{mRNA}$ increased after $12-24 \mathrm{~h}$ and stayed elevated at least up to $48 \mathrm{~h}$ ( $\mathrm{n}=3$, SEM, ${ }^{*} \mathrm{p}<0.05$, $\left.{ }^{* * * *} \mathrm{p}<0.001\right)(\mathrm{C})$ Induction of I $\mathrm{B} \zeta$ $\zeta$ mNA expression does not prevent Ad-CTS-1 induced cell death in LNT-229P cells. The cells were infected with Ad-TET$\mathrm{I} \kappa \mathrm{B} \zeta+\mathrm{Ad}-\mathrm{ON}$ in the presence (+DOX) or absence (-DOX) of doxycycline. After $24 \mathrm{~h}$, the cells were infected with increasing MOI of Ad-CTS-1. Cell density

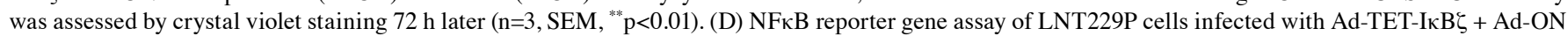
in the absence or presence of doxycycline $(n=4, S D)$.

be involved in the development of resistance and malignancy. By quantitative RT-PCR we validated $\mathrm{I} \kappa \mathrm{B} \zeta$ expression in LNT-229P and LNT-229R cells and found I $\kappa$ B $\zeta$ mRNA to be 3-fold higher in LNT-229R compared to LNT-229P cells (Fig. 1A). In contrast to normal brain where $\mathrm{I} \kappa \mathrm{B} \zeta$ is barely expressed (15), the analysis of NFKBIZ gene expression data of the TCGA database revealed that mean $\mathrm{I} \kappa \mathrm{B} \zeta$ mRNA expression was 0.65 -fold ( $\log _{2}$ scale) higher in glioblastoma samples as compared to non-neoplastic CNS control tissues (Wilcoxon test, p<0.05) (Fig. 1B). Analyses of the REMBRANDT database also exhibited an enhancement in mean $\mathrm{I} \kappa \mathrm{B} \zeta$ expression in the GBM dataset, while other glioma subgroups such as astrocytoma or oligodendroglioma showed no induction of $\mathrm{I} \kappa \mathrm{B} \zeta \mathrm{mRNA}$ expression levels as compared to normal $\mathrm{CNS}$ tissue (data not shown). In GBM cells, I $\mathrm{B}$ $\zeta$ expression was also upregulated in 3/3 tested low passage primary GBM cell lines (Tu120, Tu132, Tu140) as well as in 8/12 established glioma cell lines (Fig. 1C). In glioma specimens, I $\mathrm{B} \zeta \mathrm{m}$ RNA expression is highly variable, ranging from 1.5- (G-431) to 107-fold (G-409) compared to non-tumor brain tissue (Fig. 1D).

Overexpression of $I \kappa B \zeta$ does not influence CTS-1-induced, $N F \kappa B$-dependent cell death. In CTS-1 sensitive LNT-229P, but not in resistant LNT-229R glioma cells, NFkB is activated upon adenovirally mediated expression of CTS-1, a dominant and constitutively active version of p53 (12). In LNT-229P cells CTS-1 mediated cell death is dependent on the activity of

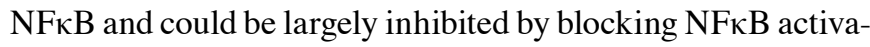
tion (12). Since in LNT-229R cells I $\kappa \mathrm{B} \zeta \mathrm{mRNA}$ is upregulated (Fig. 1A) and since it is known that $I \kappa B \zeta$ is a direct target of $\mathrm{NF \kappa B}$ and a modulator of $\mathrm{NF} \kappa \mathrm{B}$ activity, we analyzed whether in LNT-229P and LNT-229R cells I $\kappa$ B $\zeta$ mRNA expression is regulated by CTS-1 and whether enhanced $\mathrm{I} \kappa \mathrm{B} \zeta$ expression influences the CTS-1-induced cell death in these cells. As shown in Fig. 2A, I $\kappa$ B $\zeta$ expression is upregulated in Ad-CTS-1 infected LNT-229P cells that show a low basal level of I $\kappa$ B $\zeta$ expression, but is not further enhanced in Ad-CTS-1 infected LNT-229R cells which per se show elevated I $\mathrm{B}$ B $\zeta$ expression, indicating that in parental, but not in resistant cells, $I \kappa B\}$, putatively via induction of $\mathrm{NF} \mathrm{B}$, might be also regulated by CTS-1, a dominant version of $\mathrm{p} 53$.

$\mathrm{I} \kappa \mathrm{B} \zeta$ has been described, at least in fibroblasts, to bind to the NFאB p50 subunit and to interfere with p65, modulating $\mathrm{NF} \kappa \mathrm{B}$ activity and mediating the induction of several $\mathrm{NF} \kappa \mathrm{B}$ responsive genes (15). In this context, enhanced expression of I $\mathrm{I} B \zeta$ in LNT-229R cells might be the reason why these cells are resistant to CTS-1-induced cell death. To test this, we generated a tetracycline/doxycycline (DOX)-inducible adenoviral system that allows us to transiently induce $I \kappa B \zeta$ expression. After infection of glioma cells with Ad-TET-IкB $\zeta$ plus Ad-ON and addition of DOX, elevated $\mathrm{I} \kappa \mathrm{B} \zeta$ expression is detected $12 \mathrm{~h}$ after infection, increasing up to $48 \mathrm{~h}$ and 
A

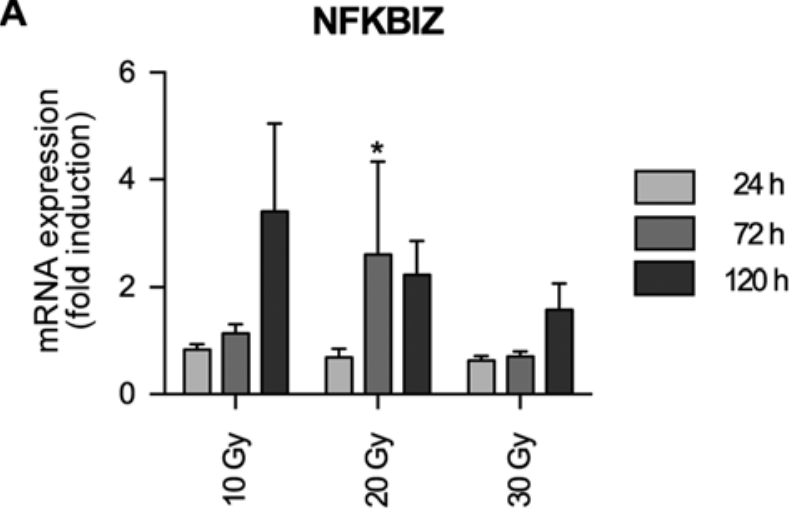

C

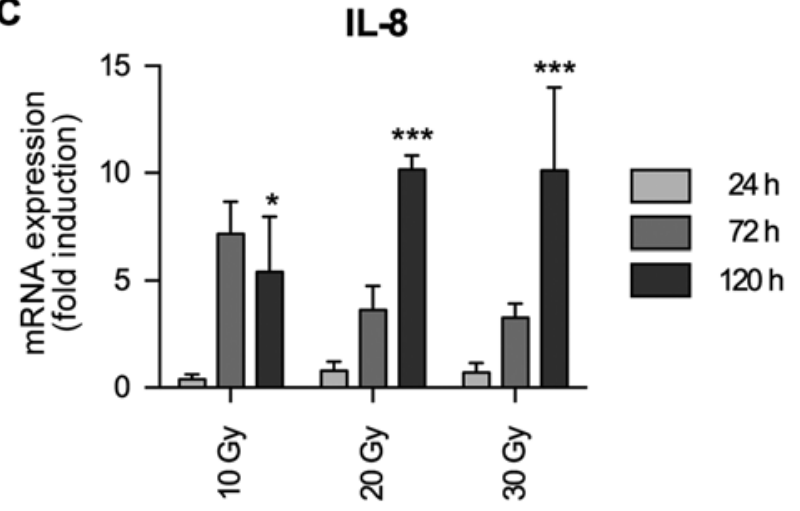

B

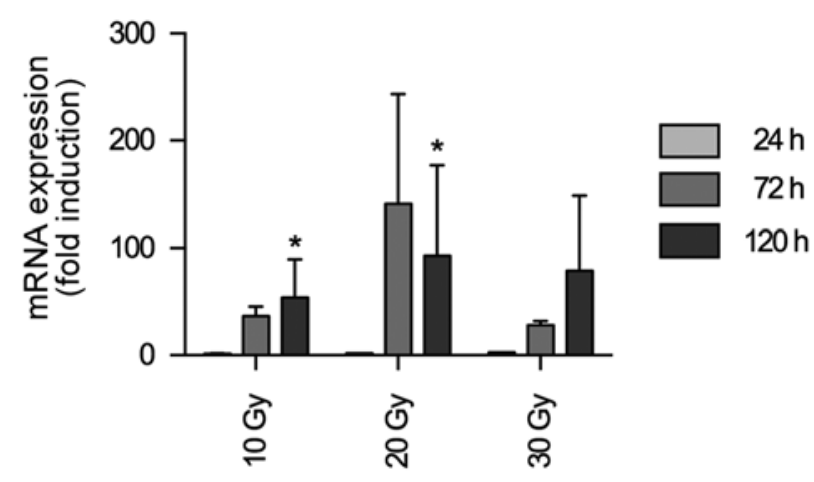

D

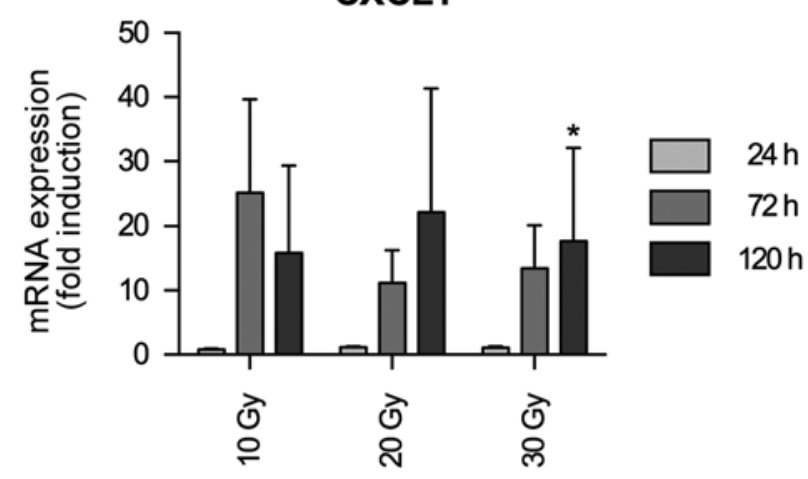

E

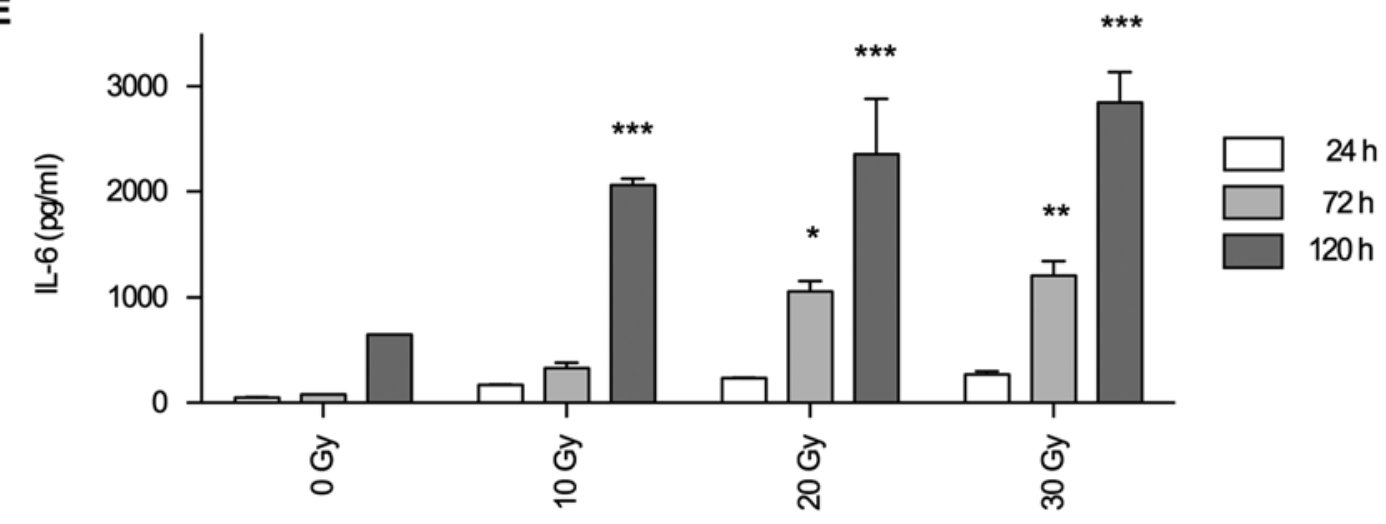

Figure 3. Irradiation of glioma cells induces the expression of I $\mathrm{K} \zeta \zeta$ and inflammatory cytokines. (A-D) mRNA expression in LNT-229P cells at different time points after irradiation. (A) I $\kappa \mathrm{B} \zeta$, (B) IL-6 (C) IL-8 and (D) CXCL1 (n=3, SEM). (E) IL-6 protein concentration in cellular supernatants of irradiated LNT$229 \mathrm{P}$ cells analyzed by ELISA $(\mathrm{n}=3, \mathrm{SEM}) .{ }^{*} \mathrm{p}<0.05,{ }^{* *} \mathrm{p}<0.01,{ }^{* * *} \mathrm{p}<0.001$.

then stable for at least $72 \mathrm{~h}$ (Fig. 2B and data not shown). Nevertheless, DOX-mediated induction of $\mathrm{I} \kappa \mathrm{B} \xi$ expression neither changed basal $\mathrm{NF} \kappa \mathrm{B}$ activity which is known to be enhanced in LNT-229 cells nor the sensitivity of these cells towards CTS-1 induced cell death (Fig. 2C and D), indicating that $\mathrm{I} \kappa \mathrm{B} \zeta$ overexpression is not responsible for the $\mathrm{NF} \kappa \mathrm{B}$ dependent resistance against CTS-1-induced cell death in LNT-229R cells.

$I \kappa B \zeta$ mRNA expression is induced by irradiation and serves as an activator for the expression of inflammation-associated cytokines IL-6, IL-8 and CXCL1. There are several hints that in glioma $\mathrm{I} \kappa \mathrm{B} \zeta$ might be a tumor promoting transcription factor, translating its oncogenic activity via induction of (chronic) inflammation. First of all, in glioma the NFKB signaling cascade is involved in processes of inflammation and resistance towards gamma-irradiation (25). Secondly, $\mathrm{I} \kappa \mathrm{B} \zeta$ as a direct target of $\mathrm{NF} \kappa \mathrm{B}$ is upregulated in fibroblasts by irradiation induced senescence and, in this regard, induces the expression of a variety inflammatory cyto- and chemokines such as interleukin (IL)-6, IL-8 and CXCL1 (19). Thirdly, IL- 6 and IL- 8 are upregulated in glioma cells upon irradiation (26), and last but not least, it has been described that IL-6 producing glioma cells were not affected by irradiation (27). We therefore investigated whether in glioma $\mathrm{I} \kappa \mathrm{B} \zeta$ might be a modulator of radiation induced expression of inflammatory cytokines. We first analyzed whether irradiation induces $\mathrm{I} \kappa \mathrm{B} \zeta$ expression. As shown in Fig. 3A, $\mathrm{I} \kappa \mathrm{B} \zeta$ mRNA expression was elevated in LNT-229P cells after irradiation. In a similar time frame, also IL-6, IL-8 


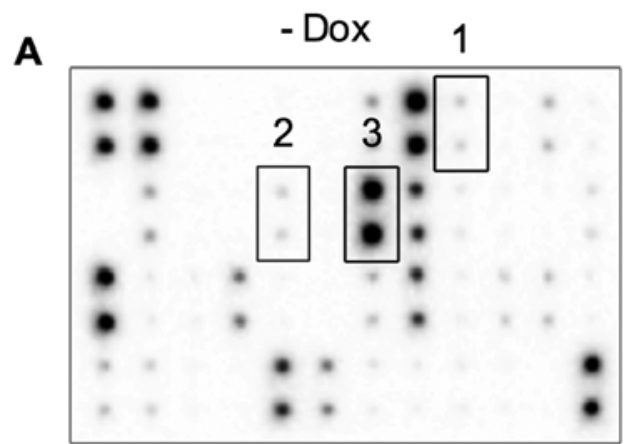

B

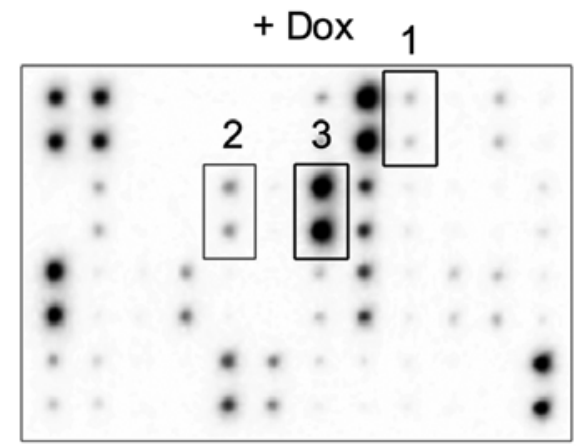

C

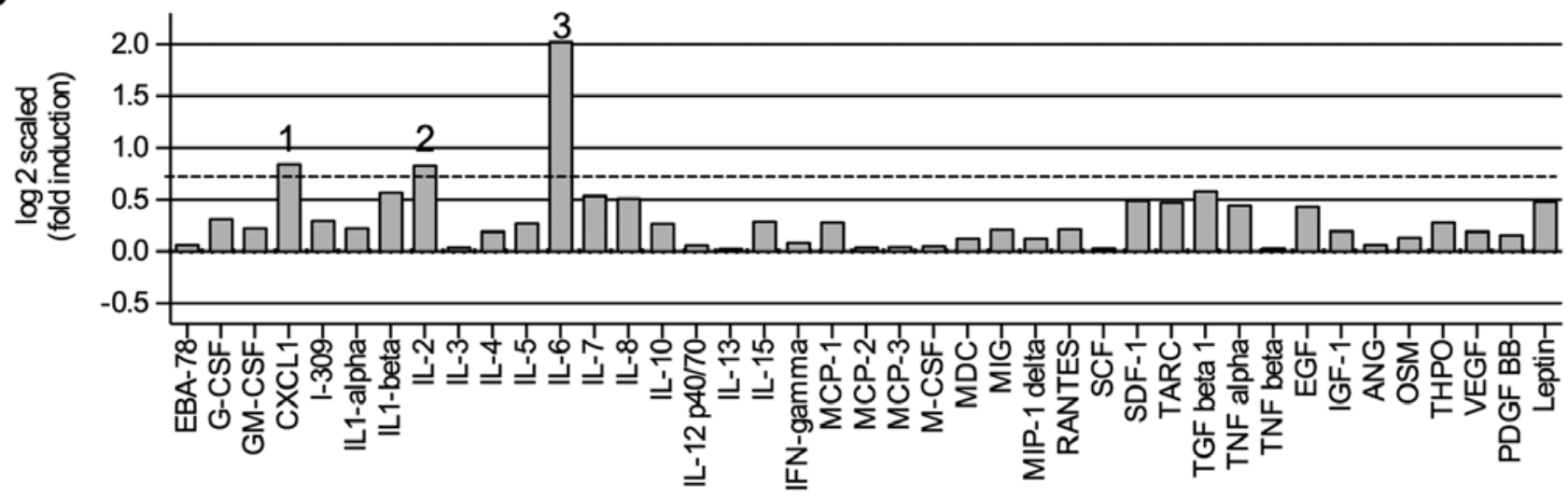

D

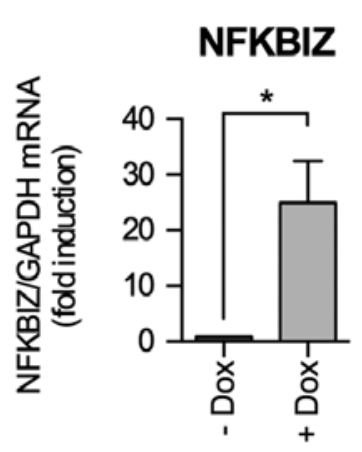

E IL-6

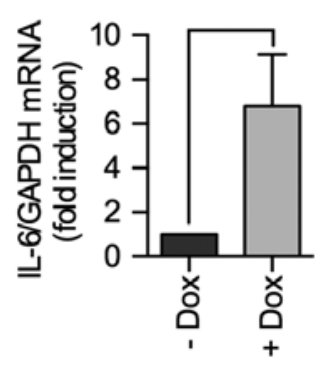

$\mathbf{F}$

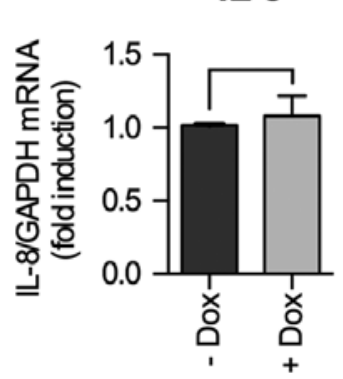

IL-8
G

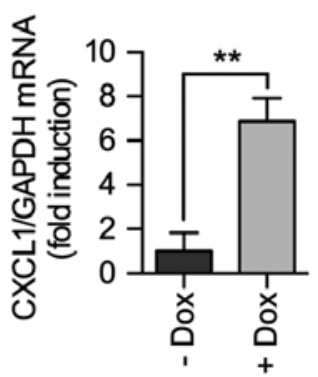

Figure 4. Overexpression of I $\mathrm{B} \zeta$ in LNT229P cells enhances the secretion of IL-6 and CXCL-1. (A and B) Semi-quantitative detection of 48 tumor-associated cytokines in supernatants of Ad-TET-I B $\zeta+$ Ad-ON infected LNT-229P cells in the presence (+DOX) or absence (-DOX) of doxycycline. (C) Quantification

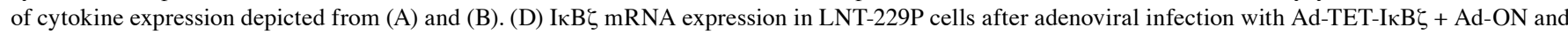
cultivation in the absence (-DOX) or presence (+DOX) of doxycycline. (D-G) mRNA expression of IkB $\zeta$ (D), IL-6 (E), IL-8 (F) and CXCL1 (G) 48 h after induction of $\mathrm{I} \kappa \mathrm{B} \zeta$ expression by adenoviral infection of LNT-229P cells with Ad-TET-I $\kappa \mathrm{B} \zeta+$ Ad-ON and cultivation in absence $(-\mathrm{DOX})$ or presence $(+\mathrm{DOX})$ of doxycycline $\left(\mathrm{n}>3, \mathrm{SEM},{ }^{*} \mathrm{p}<0.05,{ }^{* *} \mathrm{p}<0.005\right)$.

and CXCL1 mRNA expression was induced (Fig. 3B-D). To validate whether irradiation-induced expression of inflammatory cytokine mRNA in glioma cells also translates into protein expression, we exemplarily analyzed IL-6 secretion in LNT-229P cells. As shown in Fig. 3E, IL-6 secretion was upregulated by irradiation in a dose- and time-dependent manner.

We were interested whether $\mathrm{I} \kappa \mathrm{B} \zeta$ is directly responsible for the induction of IL-6, IL-8 and CXCL1 cytokine expression or if $\mathrm{I} \kappa \mathrm{B} \zeta$ served as a modulator $\mathrm{NF} \kappa \mathrm{B}$ activity as described by Totzke et al (15). For this, we infected LNT-229P cells with Ad-TET-I $\kappa \mathrm{B} \zeta+\mathrm{Ad}-\mathrm{ON}$ and induced $\mathrm{I} \kappa \mathrm{B} \zeta$ expression by addition of DOX. We used qPCR to measure cytokine mRNA expression as well as a membrane based microarray assay that allows the detection of 48 different cyto- and chemokines in cellular supernatants. We found that IL- 6 and CXCL1 were upregulated after induction of $\mathrm{I} \kappa \mathrm{B} \xi$ expression both at the level of mRNA and protein, whereas IL- 8 expression was only marginally enhanced (Fig. 4). To validate that $\mathrm{I} \kappa \mathrm{B} \zeta$ is an inducer of inflammatory cytokine expression in glioma cells, we downregulated $\mathrm{I} \kappa \mathrm{B} \zeta$ expression in irradiated LNT-229P cells by transient transfection using three different $\mathrm{I} \kappa \mathrm{B} \zeta$ specific shRNA plasmid constructs. We found $\mathrm{I} \kappa \mathrm{B} \zeta$ being downregulated to 29 (\#32), 36 (\#29) and 64\% (\#30) compared to the level of irradiated cells transfected with an unspecific shRNA plasmid construct (scrambled shRNA, Fig. 5A). By transfection of the cells using the most efficient shRNA construct (\#32), we next analyzed whether downregulation 
A

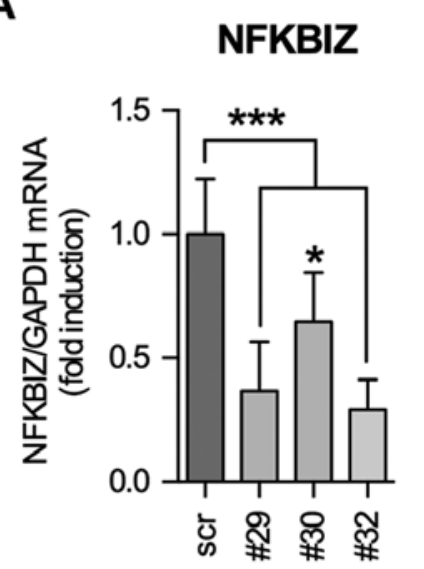

B

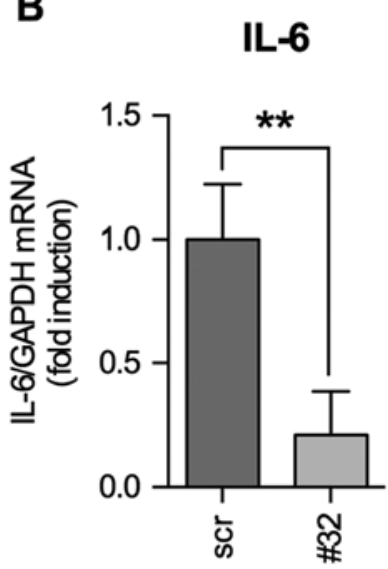

C

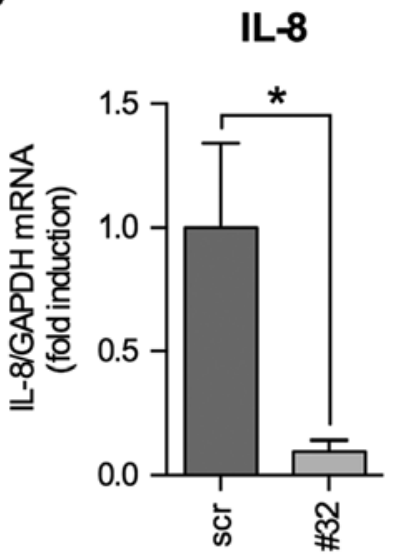

D

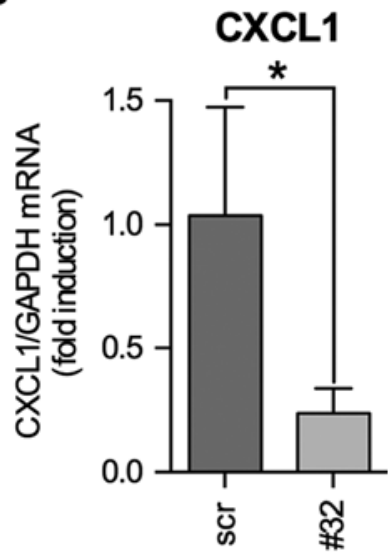

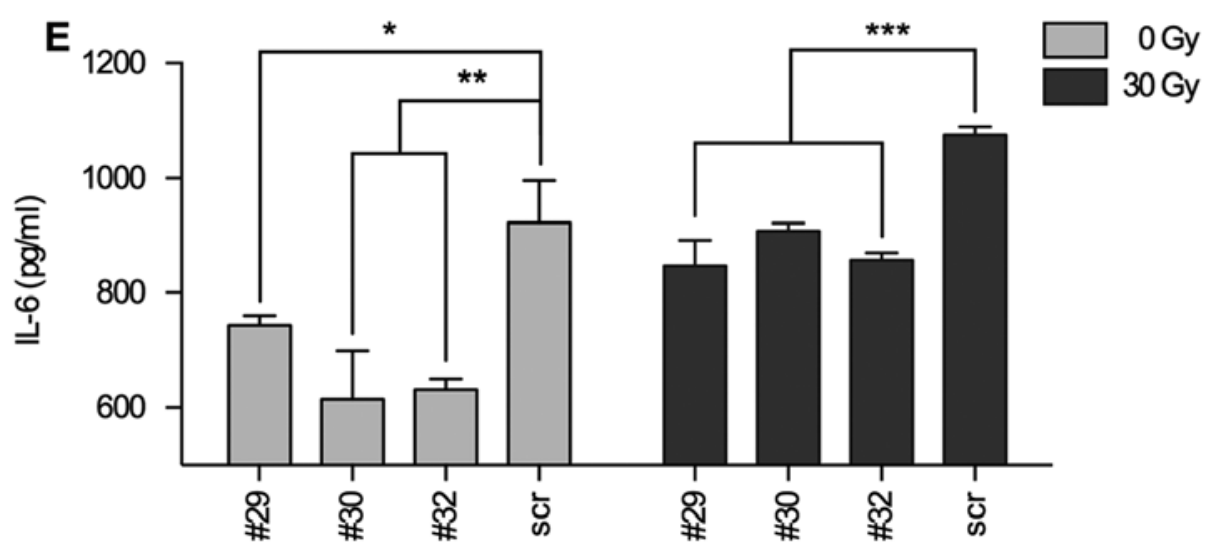

Figure 5. Downregulation of IкB $\zeta$ results in the reduction of IL-6, IL-8 and CXCL1 mRNA. (A) LNT-229 cells were transiently transfected with shRNA containing plasmids targeting IкB $(\# 29, \# 30$, \#32) or containing non-specific 'scrambled' shRNA (scr). Twenty-four hours after transfection the cells were

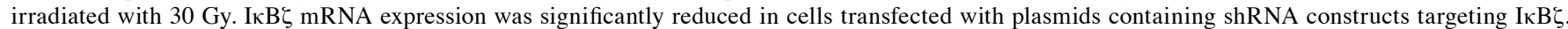
(B-D). Expression of IL-6 (B), IL-8 (C) and CXCL1 mRNA (D) was significantly reduced in irradiated LNT-229 cells transfected with the IкB $\zeta$ shRNA containing plasmid \#32. (E) IL-6 concentration in supernatants of irradiated LNT-229 cells transfected with the IкB $\zeta$ shRNA containing plasmid \#32 as detected by ELISA ( $\left.\mathrm{n}=3, \mathrm{SEM},{ }^{*} \mathrm{p}<0.05,{ }^{* *} \mathrm{p}<0.01,{ }^{* * * *} \mathrm{p}<0.001\right)$.

of I $\mathrm{I} B \zeta$ expression leads to a reduction in the expression of IL-6, IL-8 and CXCL1. Indeed, paralleled by the knockdown of IкBל, IL-6, IL-8 and CXCL1 mRNAs were downregulated. Interestingly, even if IL-8 mRNA expression was not significantly induced by the induction of IкB $\zeta$ expression (Fig. 4F), IL-8 mRNA was significantly reduced in IкB $\zeta$ knockdown LNT229P cells (Fig. 5C). Additionally, we analyzed the concentration of IL- 6 in supernatants of both, non- and irradiated LNT-229P cells transfected with either scrambled or the I $\kappa B \zeta$-specific shRNA containing plasmids (\#32). Fig. 5E demonstrates that decreased IL- 6 mRNA expression in I $\kappa$ B $\zeta$ knockdown cells is paralleled by the reduction of IL- 6 protein in the supernatants of these cells. Our results indicate a direct role of IKB $\zeta$ in the regulation of the expression of IL-6, IL-8 and CXCL1.

Expression of $I \kappa B \zeta$ and its target genes $I L-6, I L-8$ and $C X C L I$ is correlated with a poor outcome of GBM patients. To evaluate a potential association of I $\mathrm{I} B \zeta$ expression, the expression of its inflammatory cytokine targets and patients survival, we used the REMBRANDT database I $\kappa \mathrm{B} \zeta$ expression data and grouped either all glioma WHO grade II- IV (Fig. 6A) or GBM grade IV (Fig. 6B) with low or high I $\kappa \mathrm{B} \zeta$ expression. I $\kappa \mathrm{B} \zeta$ up- or down-regulation was defined as a twofold or greater difference from the mean expression level within a given dataset. Both on the early and late phase of survival analysis, patients with low $\mathrm{I} \kappa \mathrm{B} \zeta$ expression levels exhibit significantly longer survival times (glioma: $\mathrm{p}<1 \times 10^{-7}$; GBM $\mathrm{p}<1 \times 10^{-11}$ ). This analysis was repeated with a second REMBRANDT dataset revealing similar results (data not shown). These findings indicate a tumor promoting role of $\mathrm{I} \kappa \mathrm{B} \zeta$. Similar survival data were obtained for IL-6, IL-8 and CXCL1. Again, glioma patients with lower expression of either IL-6, IL-8 or CXCL1 in the tumor tissue significantly showed longer survival than patients with higher cytokine expression (Fig. 6C-E).

\section{Discussion}

Patients with GBM currently undergo standard treatment consisting of maximal surgical resection and combined radiation and chemotherapy $(28,29)$. Radiation has been a mainstay of GBM treatment for decades. Besides the therapeutic effect of radiation, side effects of this therapy approach have also been described. These unwanted and more or less tumordriving side effects include radiation-induced glioma cell migration and invasion (30-32), modulation of NFKB activity, 
A

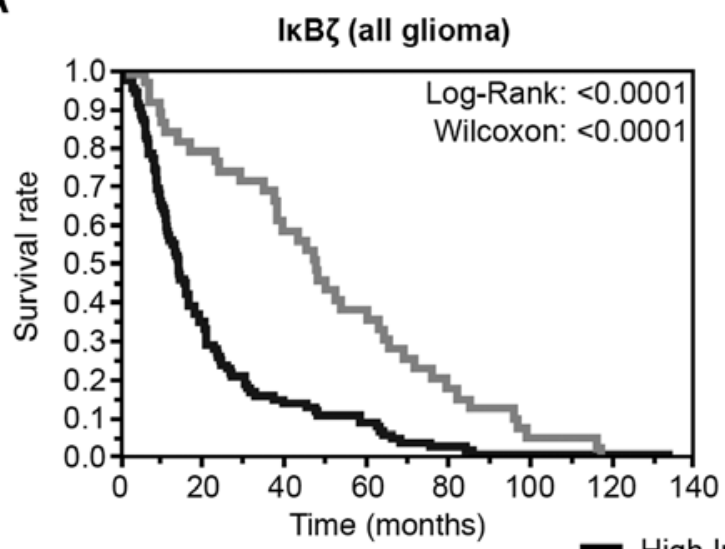

B

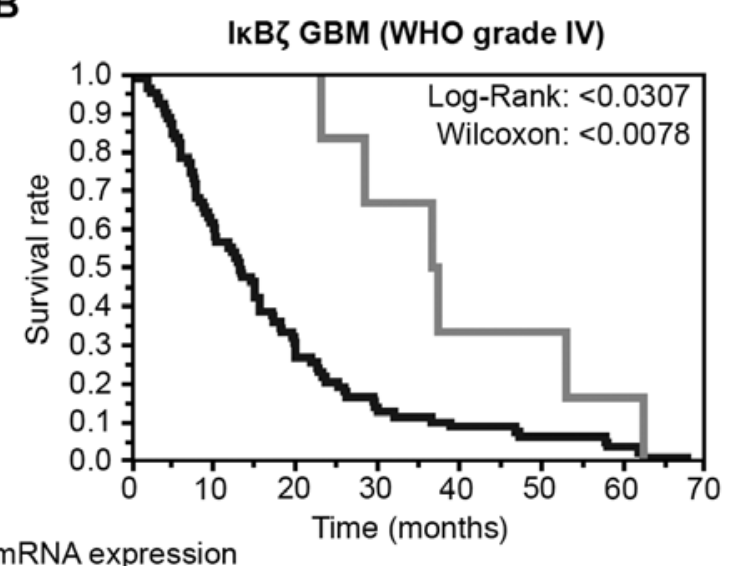

- LOW IKBZmRNA expression

C

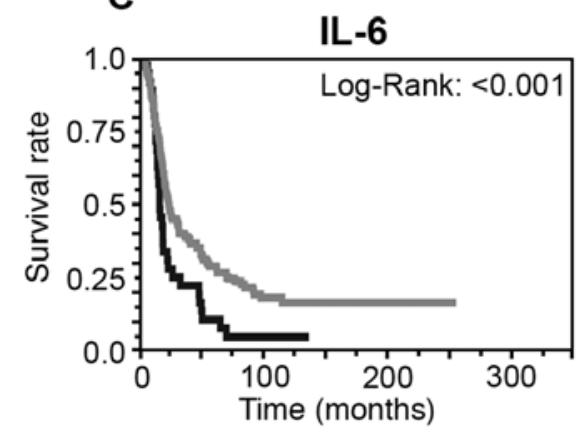

- High IL-6 mRNA expression Low IL-6 mRNA expression
D

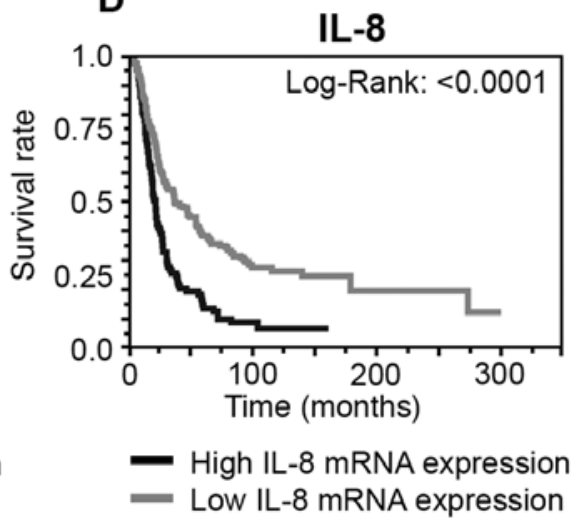

E

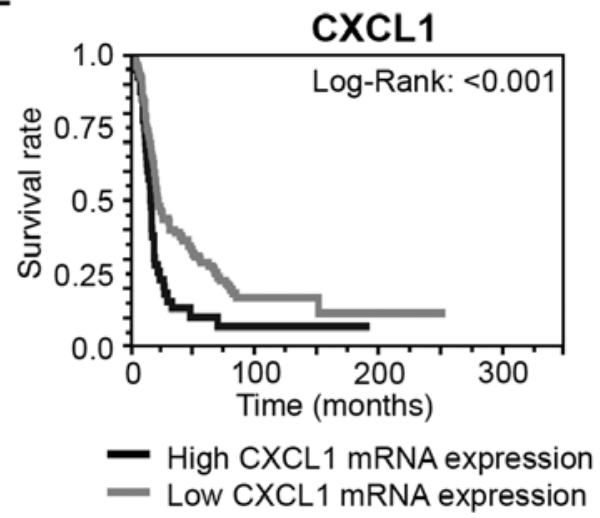

Figure 6. In glioma, enhanced I $\kappa$ B $\zeta$ or inflammatory cytokine expression correlates with poor outcome of the patients. (A and B) REMBRANDT survival analysis for glioma samples showed significantly longer survival times for patients with low expression of I $\kappa \zeta$ in a mixed cohort of gliomas WHO grade II-IV (A) as well as in GBM grade IV patients only (B). (C-E) Significantly longer survival times for glioma (WHO II-IV) patients with low IL-6 (C), IL-8 (D) and CXCL1-expression (E).

and, in this context, induction of resistance towards radiation and conversion of GBM into its most aggressive mesenchymal type subgroup $(33,34)$. Moreover, tumor irradiation can lead to cytokine and chemokine expression such as vascular endothelial factor (VEGF), IL-8, IL-6, CXCL1 and CCL2 $(19,26,32,35)$ in the tumor microenvironment, factors known to be involved in glioma progression and enhancement of the malignancy.

Our study demonstrates that the expression of the inflammatory and tumor promoting signaling molecules IL-6, IL-8 and $\mathrm{CXCL} 1$ is regulated by the atypical $\mathrm{I} \kappa \mathrm{B}$ protein $\mathrm{I} \kappa \mathrm{B} \zeta$, a direct target of $N F \kappa B$. Even if it was described that $I \kappa B\}$ inhibits transactivation of p65 and its DNA binding in HEK293 cells (15) this seems not to be the case for glioma, since no alterations of $\mathrm{NF} \kappa \mathrm{B}$ activity was detectable upon $\mathrm{I} \kappa \mathrm{B} \zeta$ overexpression in LNT-229P glioma cells (Fig. 2D), indicating a more direct effect of I $\mathrm{B} \boldsymbol{\xi} \zeta$ on the expression of IL-6, IL-8 and CXCL1 and confirming the data of Yamazaki et al who have shown that $\mathrm{I} \kappa \mathrm{B} \zeta$ independent from $\mathrm{NF} \kappa \mathrm{B}$, can directly serve as a transcription modulator of inflammatory genes (17).

Using inducible overexpression and shRNA mediated downregulation of $\mathrm{I} \kappa \mathrm{B} \zeta$ we were able to demonstrate that in glioma cells $\mathrm{I} \kappa \mathrm{B} \zeta$ serves as a transcriptional modulator of the cytokines IL-6, IL-8 and CXCL1. IL-6 is an inflammatory cytokine that is produced by human GBM cells (36), its expression is associated with the progression of glioma malignancy, putatively via induction of signal transducer and activator of transcription (STAT)-3 (37,38). IL-8, also named CXCL8, is known to drive tumorigenicity. In glioma, IL-8 is expressed both in vitro and in vivo. IL-8 plays an important role in infection and inflammation processes and it is known that its presence in the micro-milieu of glial tumors is crucial in regard to their vascularization as well as in the progression of these tumors (39). CXCL1, also known as the oncogene $\mathrm{GRO}$, binds to the G-protein coupled chemokine (C-X-C motif) receptor 2. In embryogenesis, CXCL1 regulates spinal cord development by blocking the motility of oligodendrocyte precursor cells. In adults, this cytokine is involved in processes of inflammation, angiogenesis, but also wound healing $(40,41)$. In glioma CXCL1 is highly expressed, and overexpression of CXCL1 in glioma possesses tumor cell motility and confers increased malignancy $(42,43)$.

In recent centuries, and even after the development of more efficient treatment strategies, the median survival of glioblastoma patients has only marginally improved. In this regard, novel therapeutic strategies are urgently needed to treat glioma. There are suggestions that inhibition of chronic inflammation in the tumor micro-milieu as well as reduction of glioma associated angiogenesis by inhibiting the function of glioma secreted cytokines might be successful strategies 
to treat glioblastoma. We have shown in this study that in $\mathrm{GBM}$ cells $\mathrm{I} \kappa \mathrm{B} \zeta$ is a transcriptional modulator of several protumorigenic, inflammatory or pro-angiogenic cytokines such as IL-6, IL-8 and CXCL1. Besides its function as a transcriptional activator of inflammatory cytokine expression, enhanced $\mathrm{I} \kappa \mathrm{B} \zeta$ has been demonstrated, via a transcriptionindependent mechanism, to also protect GBM cells towards necroptotic cell death, whereas knockdown of $\mathrm{I} \kappa \mathrm{B}\}$ in these cells induces necroptosis and delays tumor growth in mice (44). Furthermore, it has been described recently that $\mathrm{I} \kappa \mathrm{B} \zeta$, at least in macrophages, regulates the expression of the monocyte chemoattractant protein (MCP)-1 (14), a cytokine that is also expressed by glioma cells, recruits microglia cells into and promotes the aggressiveness of this tumor (45).

One could think that targeting $\mathrm{I} \kappa \mathrm{B} \zeta$ in the GBM micromilieu after or during radiation therapy might be an interesting novel idea for the treatment of glioma patients. However, one should also keep in mind that there might be disadvantageous effects blocking $\mathrm{I} \kappa \mathrm{B} \zeta$ in glioma: $\mathrm{I} \kappa \mathrm{B} \zeta$ has been described to regulate for the development of (glioma infiltrating) $\mathrm{T}(\mathrm{H}) 17$ cells (46). $\mathrm{T}(\mathrm{H}) 17$ cells are a subset of T cells important for the development of an efficient attack of GBM cells by immune cells, but also a subset of immune cells that are known to be inactivated by GBM released factors (reviewed in ref. 47). Therefore, a strategy targeting $\mathrm{I} \kappa \mathrm{B} \zeta$ in GBM cells exclusively might be more feasible than inhibiting $I \kappa \mathrm{B}\}$ activity in the complete GBM micro-milieu.

\section{Acknowledgements}

We thank D.G. Hildebrand and K. Schulze-Osthoff for providing us with $\mathrm{I} \kappa \mathrm{B} \zeta$-specific shRNA containing plasmids. This study was supported by the Interdisciplinary Center for Clinical Research of the University of Tübingen.

\section{References}

1. Bours V, Bentires-Alj M, Hellin AC, Viatour P, Robe P, Delhalle S, Benoit V and Merville MP: Nuclear factor-kappa B, cancer, and apoptosis. Biochem Pharmacol 60: 1085-1089, 2000.

2. Perkins ND: The diverse and complex roles of NF- $\kappa B$ subunits in cancer. Nat Rev Cancer 12: 121-132, 2012.

3. Coupienne I, Bontems S, Dewaele M, Rubio N, Habraken Y, Fulda S, Agostinis P and Piette J: NF-kappaB inhibition improves the sensitivity of human glioblastoma cells to 5-aminolevulinic acid-based photodynamic therapy. Biochem Pharmacol 81: 606-616, 2011.

4. Ding GR, Honda N, Nakahara T, Tian F, Yoshida M, Hirose H and Miyakoshi J: Radiosensitization by inhibition of IkappaBalpha phosphorylation in human glioma cells. Radiat Res 160: 232-237, 2003.

5. Zanotto-Filho A, Braganhol E, Schröder R, de Souza LH, Dalmolin RJ, Pasquali MA, Gelain DP, Battastini AM and Moreira JC: $\mathrm{NF} \kappa \mathrm{B}$ inhibitors induce cell death in glioblastomas. Biochem Pharmacol 81: 412-424, 2011.

6. Raychaudhuri B, Han Y, Lu T and Vogelbaum MA: Aberrant constitutive activation of nuclear factor kappaB in glioblastoma multiforme drives invasive phenotype. J Neurooncol 85: 39-47, 2007.

7. Zhang X, Chen T, Zhang J, Mao Q, Li S, Xiong W, Qiu Y, Xie Q and $\mathrm{Ge} \mathrm{J}$ : Notch1 promotes glioma cell migration and invasion by stimulating $\beta$-catenin and NF- $\kappa \mathrm{B}$ signaling via AKT activation. Cancer Sci 103: 181-190, 2012.

8. Xie TX, Xia Z, Zhang N, Gong W and Huang S: Constitutive NF-kappaB activity regulates the expression of VEGF and IL-8 and tumor angiogenesis of human glioblastoma. Oncol Rep 23: $725-732,2010$
9. Griffin BD and Moynagh PN: Persistent interleukin-1beta signaling causes long term activation of NFkappaB in a promoter-specific manner in human glial cells. J Biol Chem 281: 10316-10326, 2006.

10. Perkins ND and Gilmore TD: Good cop, bad cop: The different faces of NF-kappaB. Cell Death Differ 13: 759-772, 2006.

11. Ryan KM, Ernst MK, Rice NR and Vousden KH: Role of NF-kappaB in p53-mediated programmed cell death. Nature 404: 892-897, 2000.

12. Seznec J, Weit S and Naumann U: Gene expression profile in a glioma cell line resistant to cell death induced by the chimeric tumor suppressor-1 (CTS-1), a dominant-positive variant of p53 - the role of NFkappaB. Carcinogenesis 31: 411-418, 2010.

13. Perkins ND: Integrating cell-signalling pathways with NF-kappaB and IKK function. Nat Rev Mol Cell Biol 8: 49-62, 2007.

14. Hildebrand DG, Alexander E, Hörber S, Lehle S, Obermayer K, Münck NA, Rothfuss O, Frick JS, Morimatsu M, Schmitz I, et al: $\mathrm{I} \kappa \mathrm{B} \zeta$ is a transcriptional key regulator of CCL2/MCP-1. J Immunol 190: 4812-4820, 2013.

15. Totzke G, Essmann F, Pohlmann S, Lindenblatt C, Jänicke RU and Schulze-Osthoff K: A novel member of the IkappaB family, human IkappaB-zeta, inhibits transactivation of p65 and its DNA binding. J Biol Chem 281: 12645-12654, 2006.

16. Yamazaki S, Muta T and Takeshige K: A novel IkappaB protein, IkappaB-zeta, induced by proinflammatory stimuli, negatively regulates nuclear factor-kappaB in the nuclei. J Biol Chem 276: 27657-27662, 2001.

17. Yamazaki S, Matsuo S, Muta T, Yamamoto M, Akira S and Takeshige K: Gene-specific requirement of a nuclear protein, IkappaB-zeta, for promoter association of inflammatory transcription regulators. J Biol Chem 283: 32404-32411, 2008.

18. Naumann U, Kügler S, Wolburg H, Wick W, Rascher G, Schulz JB, Conseiller E, Bähr M and Weller M: Chimeric tumor suppressor 1, a p53-derived chimeric tumor suppressor gene, kills p53 mutant and p53 wild-type glioma cells in synergy with irradiation and CD95 ligand. Cancer Res 61: 5833-5842, 2001.

19. Alexander E, Hildebrand DG, Kriebs A, Obermayer K, Manz M, Rothfuss O, Schulze-Osthoff $\mathrm{K}$ and Essmann $\mathrm{F}$ : $\mathrm{I} \kappa \mathrm{B} \zeta$ is a regulator of the senescence-associated secretory phenotype in DNA damage- and oncogene-induced senescence. J Cell Sci 126: 3738-3745, 2013.

20. Krtolica A, Parrinello S, Lockett S, Desprez PY and Campisi J: Senescent fibroblasts promote epithelial cell growth and tumorigenesis: A link between cancer and aging. Proc Natl Acad Sci USA 98: 12072-12077, 2001.

21. Conti A, Gulì C, La Torre D, Tomasello C, Angileri FF and Aguennouz M: Role of inflammation and oxidative stress mediators in gliomas. Cancers (Basel) 2: 693-712, 2010.

22. Siu A, Wind JJ, Iorgulescu JB, Chan TA, Yamada Y and Sherman JH: Radiation necrosis following treatment of high grade glioma - a review of the literature and current understanding. Acta Neurochir (Wien) 154: 191-201, discussion 201, 2012.

23. He TC, Zhou S, da Costa LT, Yu J, Kinzler KW and Vogelstein B: A simplified system for generating recombinant adenoviruses. Proc Natl Acad Sci USA 95: 2509-2514.1998.

24. Grentzmann G, Ingram JA, Kelly PJ, Gesteland RF and Atkins JF A dual-luciferase reporter system for studying recoding signals. RNA 4: 479-486, 1998.

25. Tsuboi Y, Kurimoto M, Nagai S, Hayakawa Y, Kamiyama H, Hayashi N, Kitajima I and Endo S: Induction of autophagic cell death and radiosensitization by the pharmacological inhibition of nuclear factor-kappa B activation in human glioma cell lines. J Neurosurg 110: 594-604, 2009.

26. Pasi F, Facoetti A and Nano R: IL-8 and IL-6 bystander signalling in human glioblastoma cells exposed to gamma radiation. Anticancer Res 30: 2769-2772, 2010.

27. Dubost JJ, Rolhion C, Tchirkov A, Bertrand S, Chassagne J, Dosgilbert A and Verrelle P: Interleukin-6-producing cells in a human glioblastoma cell line are not affected by ionizing radiation. J Neurooncol 56: 29-34, 2002.

28. Furnari FB, Fenton T, Bachoo RM, Mukasa A, Stommel JM, Stegh A, Hahn WC, Ligon KL, Louis DN, Brennan C, et al: Malignant astrocytic glioma: Genetics, biology, and paths to treatment. Genes Dev 21: 2683-2710, 2007.

29. Hegi ME, Diserens AC, Gorlia T, Hamou MF, de Tribolet N, Weller M, Kros JM, Hainfellner JA, Mason W, Mariani L, et al: MGMT gene silencing and benefit from temozolomide in glioblastoma. N Engl J Med 352: 997-1003, 2005. 
30. Wild-Bode C, Weller M, Rimner A, Dichgans J and Wick W: Sublethal irradiation promotes migration and invasiveness of glioma cells: Implications for radiotherapy of human glioblastoma. Cancer Res 61: 2744-2750, 2001.

31. Desmarais G, Fortin D, Bujold R, Wagner R, Mathieu D and Paquette B: Infiltration of glioma cells in brain parenchyma stimulated by radiation in the F98/Fischer rat model. Int J Radiat Biol 88: 565-574, 2012.

32. Kil WJ, Tofilon PJ and Camphausen K: Post-radiation increase in VEGF enhances glioma cell motility in vitro. Radiat Oncol 7: 25 , 2012.

33. Criswell T, Leskov K, Miyamoto S, Luo G and Boothman DA: Transcription factors activated in mammalian cells after clinically relevant doses of ionizing radiation. Oncogene 22 : 5813-5827, 2003

34. Bhat KP, Balasubramaniyan V, Vaillant B, Ezhilarasan R, Hummelink K, Hollingsworth F, Wani K, Heathcock L, James JD, Goodman LD, et al: Mesenchymal differentiation mediated by $\mathrm{NF}-\kappa \mathrm{B}$ promotes radiation resistance in glioblastoma. Cancer Cell 24: 331-346, 2013.

35. Nalla AK, Gogineni VR, Gupta R, Dinh DH and Rao JS: Suppression of UPA and uPAR blocks radiation-induced MCP-1 mediated recruitment of endothelial cells in meningioma. Cell Signal 23: 1299-1310, 2011

36. Van Meir E, Sawamura Y, Diserens AC, Hamou MF and de Tribolet N: Human glioblastoma cells release interleukin 6 in vivo and in vitro. Cancer Res 50: 6683-6688, 1990.

37. Loeffler S, Fayard B, Weis J and Weissenberger J: Interleukin-6 induces transcriptional activation of vascular endothelial growth factor (VEGF) in astrocytes in vivo and regulates VEGF promoter activity in glioblastoma cells via direct interaction between STAT3 and Sp1. Int J Cancer 115: 202-213, 2005.

38. Weissenberger J, Loeffler S, Kappeler A, Kopf M, Lukes A, Afanasieva TA, Aguzzi A and Weis J: IL-6 is required for glioma development in a mouse model. Oncogene 23: 3308-3316, 2004.
39. Brat DJ, Bellail AC and Van Meir EG: The role of interleukin- 8 and its receptors in gliomagenesis and tumoral angiogenesis. Neuro-oncol 7: 122-133, 2005.

40. Tsai HH, Frost E, To V, Robinson S, Ffrench-Constant C, Geertman R, Ransohoff RM and Miller RH: The chemokine receptor CXCR 2 controls positioning of oligodendrocyte precursors in developing spinal cord by arresting their migration. Cell 110: 373-383, 2002.

41. Devalaraja RM, Nanney LB, Du J, Qian Q, Yu Y, Devalaraja MN and Richmond A: Delayed wound healing in CXCR2 knockout mice. J Invest Dermatol 115: 234-244, 2000.

42. Zhou Y, Zhang J, Liu Q, Bell R, Muruve DA, Forsyth P, Arcellana-Panlilio M, Robbins S and Yong VW: The chemokine GRO-alpha (CXCL1) confers increased tumorigenicity to glioma cells. Carcinogenesis 26: 2058-2068, 2005.

43. Robinson S, Cohen M, Prayson R, Ransohoff RM, Tabrizi N and Miller RH: Constitutive expression of growth-related oncogene and its receptor in oligodendrogliomas. Neurosurgery 48: 864-873, discussion 873-874, 2001

44. Willems M, Kroonen J, Dubois N, Berendsen S, Nguyen B, Bredel M, Artesi M, Kim H, Rados M, Chakravarti A, et al: IkappaB zeta overexpression drives human glioma resistance to necroptosis. Neuro-oncol 16 (Suppl 5): v58-v59, 2014.

45. Platten M, Kretz A, Naumann U, Aulwurm S, Egashira K, Isenmann S and Weller M: Monocyte chemoattractant protein-1 increases microglial infiltration and aggressiveness of gliomas. Ann Neurol 54: 388-392, 2003.

46. Okamoto K, Iwai Y, Oh-Hora M, Yamamoto M, Morio T, Aoki K, Ohya K, Jetten AM, Akira S, Muta T, et al: IkappaBzeta regulates $\mathrm{T}(\mathrm{H}) 17$ development by cooperating with ROR nuclear receptors. Nature 464: 1381-1385, 2010.

47. Okada H and Khoury SJ: Type17 T-cells in central nervous system autoimmunity and tumors. J Clin Immunol 32: 802-808, 2012. 